\title{
ZADOVOLJSTVO KORISNIKA USLUGAMA JAVNOG PROMETA U GRADU BEČU 4
}

\section{SAŽETAK}

Javni gradski prijevoz uključuje različite vrste usluga koje omogućavaju mobilnost građanima i stanovnicima gradova, uključujući prijevoz autobusom, vlakom, podzemnom željeznicom, trajektima, taksijima i njihovim varijacijama. Javni gradski prijevoz, pored toga, može imati i vrlo važnu i jedinstvenu ulogu u učinkovitom sustavu javnog prometa tako da omogućuje cjenovno pristupačnu mobilnost građanima koji nisu vozači, tj. nudi efikasan način putovanja urbanim sredinama te često služi kao katalizator za promišljenije i bolje upravljanje javnim zemljistem u okviru javne prometne infrastrukture. $U$ radu je dan kratak pregled javnog gradskog prijevoza grada Beča, u kojem se javnim prijevozom s lakoćom može stići do skoro bilo kojeg dijela, a koriste se nove tehnologije koje olakšavaju svakodnevno putovanje pojedinaca javnim gradskim prijevozom. $U$ suvremenim gradovima promet je jedan od najvećih problema. Veliki gradovi previše su opterećeni zastojima u prometu, nedostatkom mjesta za parkiranje, onečišćenim zrakom, bukom te konfliktom motornih vozila i pješaka. Svi ovi problemi modernog doba u kojem prometna potražnja nadilazi prometnu ponudu ne dolaze do izražaja kada se karakterizira javni gradski prijevoz ovog europskog grada. Gradske vlasti i vodeće prometno poduzeće Wiener Linien ulažu velike napore u smanjenje onečišćenja izagađenja okoliša prometom. Za poticanje korisnika u korištenju javnog prijevoza i smanjenju korištenja osobnih automobila, grad Beč nudi na prvom mjestu velike alternativne izbore kao što je korištenje gradskih bicikala i izgradnja velikog broja biciklističkih staza, kao i carsharing (dijeljenje automobila). Predmet istraživanja ovog rada jest istražiti i utvrditi anketnim upitnikom zadovoljstvo korisnika usluga javnog gradskog prijevoza u gradu Beču.

Ključne riječi: javni gradski prijevoz, usluge, zadovoljstvo korisnika

\section{UVOD}

Povećana potražnja i preferencija u uporabi osobnih prijevoznih sredstava za prijevoz uzrokuje brzorastuću motorizaciju u mnogim zemljama svijeta. Većina stanovnišsva u današnjem suvremenom svijetu visoko je ovisna o privatnom motoriziranom prijevozu. Ovaj fenomen vidljiv je diljem svijeta upravo zbog privlačnosti osobnih automobila i preferencija za osobnom vožnjom većine stanovništva, odnosno rezidenata pojedinih zemalja u svijetu. Povećana upotreba motoriziranih privatnih prijevoznih sredstava, kao što su osobni automobili, najčešće rezultira čestim prometnim gužvama na prometnicama koje nadalje prouzrokuju da vrijeme putovanja do odredišta traje duže. Pored prometnih gužvi, uporaba privatnih motoriziranih prijevoznih

Mr. sc., predavač, Veleučilište u Rijeci, Vukovarska 58, 51000 Rijeka, Hrvatska. E-mail: mgolob@veleri.hr

Studentica, Veleučilište u Rijeci, Vukovarska 58, 51000 Rijeka, Hrvatska.

Univ. spec. oec., asistent, Veleučilište u Rijeci, Vukovarska 58, 51000 Rijeka, Hrvatska.E-mail: martin.golob@veleri.hr Datum primitka rada: 15. 1. 2017.; datum prihvaćanja rada: 15. 3. 2017. 
sredstava također negativno djeluje na sigurnost sudionika u prometu, koji time postaju sve ranjiviji i izloženiji raznim rizicima. Nadalje, visoka razina uporabe neobnovljivih izvora energije za pokretanje spomenutih prijevoznih sredstava negativno djeluje na okoliš u kojem sudinici prometa obitavaju. U vidu smanjenja negativnih posljedica pretjerane uporabe osobnih automobila i drugih privatnih motoriziranih prijevoznih sredstava, gradovi i mnoge zemlje diljem svijeta pokušavaju ponuditi alternativan način prijevoza kako bi olakšali svakidašnji tranzit i ubrzali ga za njegove sudionike. Javni gradski prijevoz, odnosno javni promet u svojoj ukupnosti, trebao bi u bližoj budućnosti postati dio rješenja za održivi način transporta. No, da bi javni gradski prijevoz zadržao, ali i privukao veći broj putnika, odnosno korisnika navedenog prijevoza, mora ponuditi i omogućiti visoku razinu kvalitete usluge kako bi zadovolji širok spektar potreba velikog broja različitih korisnika. Zbog navedenog, vrijedno je istraživati i sakupljati znanje i nove spoznaje o tome što utječe na zadovoljstvo korisnika javnog gradskog prijevoza, ali i što utječe na nezadovoljstvo korisnika javnog gradskog prijevoza, kako bi sakupljena i dostupna znanja bila podloga i temelj za osmišljavanje i dizajn atraktivnih i učinkoviti javnih gradskih mreža prijevoza. Važno je napomenuti da osim pružanja visoke razine usluge, javna ali i privatna poduzeća koja su dionici javnog gradskog prijevoza diljem svijeta moraju voditi računa i o tržišnoj usmjerenosti javnog gradskog prijevoza, odnosno, da bi korisnici koristili javni gradski prijevoz i kupovali karte za prijevoz i time omogućili daljnje poslovanje prije spomenutim poduzećima, mora postojati zadovoljstvo korisnika kako bi taj prijevoz i dalje nastavili koristiti. Vrlo često u takvim uvjetima, gdje je tržišna usmjerenost poduzeća čija je djelatnost javni gradski prijevoz, navedeni poslovni subjekti moraju pribjegavati i koristiti druge načine pribavljanja novčanih sredstava koja će u konačnici pridonijeti opstanku na tržištu ili manjoj ovisnosti provođenja operativnih aktivnosti javnog gradskog prijevoza od strane državnih donacija ili drugih sredstava. Budući da javni gradski prijevoz, u konačnici, koristi veći broj korisnika, prijevozna sredstva javnog gradskog prijevoza idealno su mjesto za različite poslovne subjekte i njihove marketinške stručnjake glede oglašavanja. Oglašavanje na površinama javnih gradskih prijevoznih sredstava, izvan i unutar njih, na taj način postaje značajan način pribavljanja dodatnih novačnih sredstava za poduzeća javnog gradskog prijevoza i važan čimbenik akumulacije kapitala potrebne za provođenje operativnih aktivnosti ili unaprjeđenje kvalitete usluge. Shodno svemu navedenome postavljena su tri istraživačka pitanja:Jesu li korisnici javnog gradskog prijevoza u gradu Beču zadovoljni uslugama koje javni gradski prijevoz svojim korisnicima pruža? Kako korisnici javnog gradskog prijevoza u gradu Beču percipiraju prisutnost oglašavanja, odnosno marketinških aktivnosti tijekom korištenja navedenog prijevoza? Ima li prisutnost marketinških aktivnosti, ponajprije oglašavanja, utjecaj na zadovoljstvo korisnika usluga javnog gradskog prijevoza u gradu Beču?

Ovim radom pokušat će se dati doprinos razvitku javnog gradskog prijevoza za sve zainteresirane stranke, posebice u Republici Hrvatskoj, što je i svrha rada i provedenog istraživanja. Provedeno istraživanje ima za cilj istražiti i utvrditi razinu zadovoljstva korisnika uslugama javnog gradskog prijevoza u gradu Beču, kako bi se na taj način došlo do temeljnih spoznaja za unaprjeđenje domaćih ali i drugih javnih gradskih usluga prijevoza. U nastavku dan je prikaz teorijskih pretpostavki vezanih uz temu i rezultati provedenog istraživanja. 


\section{ZADOVOLJSTVO KORISNIKA USLUGAMA U JAVNOM GRADSKOM PRIJEVOZU}

Ekonomika prometa dio je ekonomske znanosti o zakonitostima, međuovisnosti i razvoju pojedinih prometnih grana i prometa. Točnije se definira kao znanstvena disciplina koja pokušava proučavati i sistematizirati specifične zakonitosti prijevoznog procesa, koje su nadalje rezultat njegovih gospodarskih obilježja. Sažeto, ekonomika prometa proučava alokaciju transportnih resursa tako da se susretnu potrebe društva (Pupavac, 2009). Javni gradski prijevoz kao predmet proučavanja ekonomike prometa od vitalne je važnosti za mnoge gradove diljem svijeta, pogotovo za velike multimilijunske gradove i velika gradska turistička središta poput Rima, Pariza i sličnih gradova. Javni gradski putnički prijevoz poznat je kao javni gradski prijevoz ili javni masovni prijevoz, a sastoji se od prijevoznih sredstava s ustaljenim trasama koja prometuju prema unaprijed utvrđenom voznom redu. Korištenje je omogućeno svakome tko plati cijenu prijevoza prema unaprijed utvrđenoj tarifi (Rajsman, 2012). Kada stanovnici koriste usluge javnog gradskog prijevoza umjesto osobnih motoriziranih prijevoznih sredstava, poput osobnih automobila ili motocikala, onečišćenje okoliša u tim gradovima reducira se te se razina buke snižava i niže je razine, što u mnogočemu pridonosi kvaliteti življenja u navedenim velikim gradskim središtima u kojima je ujedno turistička djelatnost od presudne važnosti za gospodarski sustav grada. Na taj način i turistički posjetitelji mogu više cijeniti doživljaj takvih gradova i turističkih središta uz korištenje učinkovitih prijevoznih sredstava javnih gradskih transportnih mreža. U svemu navedenom leži težnja za poboljšanjem takvih usluga. Prema Zamazálovoj (2009) viša razina zadovoljstva korisnika značajno pridonosi lojalnosti korisnika, stoga bi pružatelji usluge trebali postići najveću razinu zadovoljstva korisnika svojim uslugama. Prema autorima Shiau, Luo (2012) zadovoljstvo korisnika pozitivno djeluje na napor poslovnih subjekata u uspostavljanju dugoročnih odnosa s korisnicima njihovih usluga ili proizvoda. Naposljetku, uspjeh javnog gradskog prijevoza ovisi o samom broju putnika, odnosno korisnika koje je javni gradski prijevoz sposoban privući i zadržati. Posljedično, kvaliteta usluga koje nude poduzeća čija je djelatnost javni gradski prijevoz od izuzetne je važnosti. Kako navodi Mouwen (2015) javni gradski prijevoz u zapadnjačkim zemljama uglavnom obavljaju poduzeća na osnovi ugovora s javnom upravom koja je zadužena za javni prijevoz te navedene usluge pružaju privatni ili polujavni poslovni subjekti koji djeluju na tržištu u gotovo monopolističkim uvjetima. Kako autor nadalje objašnjava, navedeno rezultira nepostojanjem natjecateljskog tržišta između nekoliko jednakopravnih sudionika na kojem bi zadovoljstvo korisnika bilo od presudne važnosti za daljnje poslovanje. Vrlo često se događa da se poduzeća, odnosno poslovni subjekti koji pružaju usluge javnog gradskog prijevoza, više fokusiraju na zadovoljstvo javne uprave koja im je dodijelila pravo pružanja usluga javnog gradskog prijevoza nego na zadovoljstvo korisnika. Zadovoljstvo korisnika često se zna zanemarivati, dok je na natjecateljskom tržištu ono isto vrlo važna stavka u planiranju poslovanja. Navedeno ipak ne isključuje činjenicu da je zadovoljstvo korisnika uslugama svejedno važan faktor prilikom obavljanja usluga javnog gradskog prijevoza, budući da uspješnost javnog gradskog prijevoza, prema ranijima navodima, ovisi o tome koliko je sposoban privući i zadržati svoje korisnike. Navedeno podržava i činjenica da se u mnogim zemljama diljem svijeta velika novčana sredstva investiraju u javne transportne sustave upravo kako bi ih se učinilo kompetitivnijim vidom transporta u odnosu na druge modalitete transporta putnika, odnosno korisnika usluga javnog gradskog prijevoza, posebice prijevoza osobnim automobilima. 
Konstantno se razvijaju nove usluge u javnom gradskom prijevozu, dok se stare usluge stalno unaprjeđuju. Upravo zbog osiguravanja da takve velike investicije $u$ javne prijevozničke mreže poluče zadovoljavajuće rezultate, zadrže stare korisnike i privuku nove, znanje o zadovoljstvu uslugama trebalo bi omogućiti svim dionicima i operativnim upraviteljima takvih sustava vrlo vrijedne informacije (Nathanail, 2007). Zadovoljstvo korisnika uslugama javnog prijevoza koje pružaju poduzeća u javnom sektoru često nema drugih značajnih pokazatelja uspješnosti osim samog zadovoljstva korisnika njihovim uslugama.

Provedeno istraživanje Europske komisije o zadovoljstvu korisnika javnog gradskog prijevoza europskih građana (ec.europa.eu, 2014) rezultiralo je spoznajom da je više od tri četvrtine europskih građana koristilo javni gradski prijevoz najmanje jednom u životu, i to $76 \%$ ispitanika koji su sudjelovali u istraživanju. Diljem Europske unije oko trećine ispitanika koristi javni gradski prijevoz najmanje jednom u tjednu (32\%). Provedenim istraživanjem došlo se do spoznaje da europski građani imaju povoljan pristup javnom gradskom prijevozu te do podatka da je više od tri četvrtine europskih građana (77\%) udaljeno manje od deset minuta od najbliže stanice javnog gradskog prijevoza. Provedenim istraživanjem došlo se do zaključka da su europski građani uglavnom zadovoljni svim aspektima javnog gradskog prijevoza s iznimkom zadovoljstva u pogledu cijene karte javnog gradskog prijevoza. Navedeno istraživanje nadahnulo je autore rada na sličan poduhvat, no u mnogo manjem obujmu i s fokusom samo na grad Beč.

\section{KARAKTERISTIKE JAVNOG GRADSKOG PRIJEVOZA U GRADU BEČU}

Danas grad Bečima visokorazvijen sustavjavnog gradskog prijevoza. Autobusi, tramvaji i podzemna željeznica mogu odvesti korisnike javnog gradskog prijevoza na bilo koju od brojnih lokacija na širem području grada u najkraćem mogućem roku.

Wiener Linien naziv je poduzeća koje se brine za najveći dio javnog gradskog prijevoza u gradu Beču, a koje svoje poslovanje obavlja u sastavu gradskog holdinga "Wiener Stadtwerke Holding AG". Prijevozničko poduzeće Wiener Linien upravlja najvećom prometnom mrežom u Austriji sa 78,5 kilometara U-Bahna (podzemna željeznica), 220 kilometara tramvajskih linija te ukupno 850 kilometara linija autobusnog prijevoza. U 2015. godini u prijevozu prijevozničkog poduzeća Wiener Linien izbrojeno je preko 939 milijuna putnika (dva i pol milijuna vožnji po danu). Prema statističkim podacima dokazano je da u gradu Beču $39 \%$ ispitanika koristi vozila javnog gradskog prijevoza, $27 \%$ koristi osobne automobile, $7 \%$ njih putuje biciklom dok njih $26 \%$ pješači (www.wienerlinien.at, 2016). Prijevozničko pouzeće Wienen Linien upravlja s 5 linija podzemne željeznice, 29 tramvajskih i 127 autobusnih linija, od kojih su 24 linije noćnog prijevoza. Noćne linije operativno su aktivne od $00.30 \mathrm{~h}$ do $05.00 \mathrm{~h}$, dok tijekom vikenda i javnih praznika bečka podzemna željeznica operativno djeluje čitave noći. Trenutno se vozni park grada Beča sastoji od preko 150 vlakova podzemne željeznice, preko 500 tramvajskih vagona i više od 450 autobusa, te je bečki javni gradski prijevoz dio Verkehrsverbund Ost-Region VOR-a, odnosno prijevozničkog udruženja u južnim dijelovima Austrije (www.wien.gv.at, 2017). Svakodnevno se prijevoznim sredstvima prijevozničkog poduzeća Wiener Linien prevozi oko 260.000 ljudi, što je više korisnika prijevoza od broja stanovnika drugog najvećeg grada po veličini u Austriji, Graza. S preko 8.700 zaposlenika prijevozničko poduzeće Wiener Linien također je i jedan od najvećih poslodavaca u 
gradu Beču. Oko 4.000 vozača U-Bahna, tramvaja i autobusa bitan su dio strukture zaposlenika prijevozničkog poduzeća Wiener Linien kao i ostali zaposlenici: mehaničari, inženjeri i svi ostali zaposlenici koji svakodnevno rade na održavanju mreže prijevoza, stanica i signala. Svake godine poduzeće prima i do 15.000 zamolbi za posao. Cilj u budućnosti za prijevozničko poduzeće Wiener Linien je do 2020. godine imati preko milijardu putnika u jednoj godini, raditi na unaprjeđenju i stvaranju novih vrsta mobilnosti te učiniti poduzeće još više ekološki osviještenim i inovativnim (www.wienerlinien.at, 2016). Zanimljiva je činjenica da je krajem 2015. godine broj korisnika javnog gradskog prijevoza u gradu Beču koji imaju godišnju kartu (700.000 izdanih godišnjih karti) prešao broj registriranih prijevoznih sredstava (685.000 registriranih vozila). Od tada, broj izdanih godišnjih karti kontinuirano je u porastu te je na početku 2017. godine iznosio 733.000 izdanih godišnjih karti za javni gradski prijevoz (www.wienerlinien.at, 2017).

Bečka podzemna željeznica (Wiener U-Bahn) sustav je podzemnog javnog gradskog prijevoza u glavnom gradu Austrije - Beču. Dnevno ovim sustavom javnog gradskog prijevoza u gradu Beču putuje oko 1,300.000 putnika, odnosno korisnika usluga javnog gradskog prijevoza. Uz ovaj sustav na području grada Beča prometuju još i prigradski vlakovi (S-Bahn), koji također kroz grad Beč prolaze podzemnim putem. $U$ usporedbi s ostalim velikim i sličnim gradovima svijeta bečki je sustav podzemne željeznice relativno novijeg datuma. No pitanje gradnje podzemne željeznice u Beču protezalo se godinama, pa su tako u razdoblju od 1844. do 1960-ih iskušavane razne varijante sustava javnog prijevoza. Gradnja podzemne željeznice s vremenom je postala nužna, budući da je javni gradski promet pokazivao znakove ubrzanog rasta, pa postojeći tramvajski sustav više nije bio dovoljno učinkovit u opsluživanju i zadovoljenju njegovih korisnika. Radovi na podzemnoj željeznici u gradu Beču započeli su 26. siječnja 1968. godine, a prvo se gradila osnovna mreža u duljini od oko 30 km. Otvorenje prve dionice bilo je 8. svibnja 1976. godine (Wiener Linien GmbH \& Co KG, 2015). Glavni poticaji za implementaciju održive transportne politike u gradu Beču bilo je izrazito povećanje problema prouzročenih povećanom uporabom motoriziranih prijevoznih sredstava, posebice osobnih automobila u 1970-im godinama. Navedeno je prouzrokovalo prometne gužve, nedostatak parkirnih mjesta, zagađenje zraka, visoke razine buke, prometne nesreće i ozljede u prometu, deterioraciju povijesne jezgre grada zbog uporabe motoriziranih prijevoznih sredstava i gubitak javnih površina zbog nepropisnih parkiranja osobnih automobila diljem grada. Povećana kupnja i upotreba osobnih automobila posebno je bila problematična u centralnim dijelovima grada Beča, točnije povijesnoj jezgri koja je skučenija od ostalih dijelova grada i koju karakterizira nekoliko širih ulica i brojne uže i manje ulice. Inicijalna konstrukcija i naknadna ekspanzija sustava metroa u gradu Beču (U-Bahn) trebala je ubrzati javni transport. Godišnja karta uvedena 2011. godine u iznosu od 365 eura trebala je pospješiti popularizaciju korištenja javnog gradskog prijevoza kako bi se uporaba osobnih automobila smanjila. Osnovana je i kasnije proširena i uprava zadužena za parkirališta na području grada kako bi se grad Beč učinkovitije borio s ekstremnim problemom nedostatka parkirnih mjesta u središnjim dijelovima grada, kao i dodatnim prometnim gužvama, onečišćenjem zraka i visokom razinom buke prouzročenom kruženjem automobila u traženju parkirnog mjesta. Donedavno su problemi prometa u gradovima, pa tako i gradu Beču, gledani uglavnom kao tehnički problemi izvan političkih odluka, bez konzultiranja javnosti. Posljednjih godina proces donošenja odluka u prometu se promijenio jer je političke stranke, grupe građana 
i ekološke udruge aktivirao u izražavanju zahtjeva korisnika prijevoznih usluga (homepage.univie. ac.at, 2017).

Grad Beč mnogo ulaže i u razvoj biciklističkog prometa kao legitimnog oblika javnog gradskog prijevoza. Gradski servis grada Beča Vienna Citybike je javni sustav unajmljivanja bicikala koji omogućava da se svi njegovi korisnici koristeći bicikl kao prijevozno sredstvo mogu olakšano kretati diljem grada, i to po mnogo nižem trošku prijevoza nego što bi to bio da koriste druge modalitete javnog gradskog prijevoza u gradu Beču. Trenutno je korisnicima ove usluge koju grad Beč pruža na raspolaganju oko 1.500 bicikala koji su dostupni na oko 120 lokacija, odnosno na 121 terminalu diljem grada. Korištenje ovog servisa od njegove implementacije u javni gradski sustav grada Beča imalo je samo pozitivne odjeke kod njegovih korisnika, podjednako i kod stanovnika grada Beča i kod turističkih posjetitelja. Posebna web-stranica u sklopu servisa olakšava snalaženje u razgranatoj mreži terminala i biciklističkih ruta diljem grada Beča. Navedena web-stranica optimizirana je za mobilne uređaje i nudi sveobuhvatne informacije o prije spomenutim terminalima. Navedeni servis pokrenut je 2003. godine. Do sada je broj registriranih korisnika prešao broj od 480.000, te je zabilježeno povećano korištenje bicikala dostupnih putem servisa u jutarnjim i kasnim poslijepodnevnim terminima (www.wien.gv.at, 2017).

Od ostalih specifičnosti javnog gradskog prijevoza grada Beča vrijedno je spomenuti dijeljenje automobila (engl. Carsharing). Navedeni pojam, odnosno usluga, temelji se na članstvu koje omogućava svim kvalificiranim vozačima upotrebu, odnosno sukorištenje prijevoznih sredstava, ponajprije osobnih automobila, umjesto posjedovanja vlastitog osobnog automobila (CarSharing Association, 2011). Na području grada Beča postoji nekoliko pružatelja takvih usluga kao što su Zipcar, Car2go, DriveNow i ostali. Navedena usluga značajno pridonosi smanjenju broja osobnih automobila u prometnom sustavu grada Beča.

\section{REZULTATI EMPIRIJSKOG ISTRAŽIVANJA}

Predmet ovog rada su rezultati empirijskog istraživanja razine zadovoljstva korisnika uslugama javnog gradskog prijevoza grada Beča. Rezultati provedenog empirijskog istraživanja prikazat će se tabelarno te će se u popratnom tekstu prikazati analiza dobivenih rezultata, odnosno prikazati glavni rezultati provedenog istraživanja dobiveni anketiranjem korisnika usluga javnog gradskog prijevoza u spomenutom austrijskom gradu koji je ujedno i poznato turističko odredište u Srednjoj europi.

\section{1 Definiranje problema i metodologije istraživanja}

Kao što je navedeno u prijašnjim poglavljima ovog rada, zadovoljstvo korisnika uslugama javnog gradskog prijevoza od iznimne je važnosti za unaprjeđenje svih aktivnosti javnog gradskog prijevoza te je važna stavka koja se mora uzeti u obzir prilikom upravljanja sustavom javnog gradskog prijevoza. Ispitivanjem korisnika i analiziranjem dobivenih rezultata svi dionici javnog gradskog prijevoza, posebice rukovoditelji tih jako složenih prijevoznih sustava, mogu dobiti vrijedne informacije u funkciji unaprjeđenja usluge ali i povećanja zadovoljstva samih korisnika, što naravno može imati pozitivne učinke na daljnje operativno provođenje aktivnosti u javnom gradskom prijevozu, uz osiguravanje efikasnog poslovanja poduzeća koje te aktivnosti provode. 
Važno je napomenuti da se svaki proizvod ili usluga konstantno mora prilagođavati potrebama i zahtjevima korisnika, odnosno potrošača, a istraživanje zadovoljstva korisnika svakako pridonosi sakupljanju vrijednih informacija u tom pogledu.

Provedeno je istraživanje o percepciji kvalitete usluge u javnom gradskom prijevozu grada Beča. Anketni upitnik proveden je u vremenskom razdoblju između 22. 9. 2016. godine i 18. 10. 2016. godine. U provođenju istraživanja sudjelovalo je 97 ispitanika. Ispitanici su na anketu odgovarali internetom na društvenoj mreži „Facebook" te e-mailom, a najveći dio odgovorio je usmeno. Uz podatke o strukturi anketnog uzorka (dob i spol ispitanika, stručna sprema i ostale), učestalosti korištenja (broj vožnji dnevno, tjedno, mjesečno i dr.), načinom korištenja (vrste kupljenih voznih karata, mjesta kupnje voznih karata i sl.) i općenitom zadovoljstvu korisnika, ovim istraživanjem prikupljeni su podaci o specifičnim aspektima usluge javnog gradskog prijevoza. Točnije, ispitivana je razina korisničkog zadovoljstva: točnošću autobusa i tramvaja (poštovanju voznog reda), brojnošću i frekventnošću (učestalošću nailaska vozila), zagušenošću unutar vozila, tolerancijom presjedanja, udobnošću vozila i stajališta, čistoćom vozila, sigurnošću u vozilima, cijenama usluga prijevoza te informiranošću. Korisnici usluga javnog gradskog prijevoza u gradu Beču dobrovoljno su sudjelovali u istraživanju koje je bilo anonimne prirode. Sam anketni upitnik sastavljen je po uzoru na slična istraživanja provedena u Europskoj uniji i Republici Hrvatskoj.

\section{2 Sociodemografski profil ispitanika}

Sociodemografski profil korisnika usluga javnog gradskog prijevoza u gradu Beču sagledao se kroz varijable spola ispitanika, njihove starosne strukture, stupnja obrazovanja, radnog statusa i njihovih ukupnih prihoda. U provedenom empirijskom istraživanju sudjelovalo je 97 ispitanika. Što se tiče strukture ispitanika prema spolu, ispitanica je bilo više (68 \%), dok je broj ispitanika muškog spola bio manji (32\%).

Provedeno empirijsko istraživanje također je pokazalo da je najveći broj ispitanika bio u starosnoj skupini između 20 i 29 godina (70\%), dok je sljedeća najzastupljenija starosna skupina između 40 i 59 godina (12,4\%). Najmanje zastupljenija starosna skupina ona je od 60 i više godina (2 \%), koju slijedi starosna skupina između 15 i 19 godina (5,2 \%), te srednja starosna skupina između 30 i 39 godina (10,3\%). Struktura stupnja obrazovanja ispitanika podijeljena je na samo osnovnoškolsko obrazovanje, izučeni zanat, srednjoškolsko obrazovanje, višu stručnu spremu, magisterij i doktorat. Od ukupnog broja ispitanika koji su obuhvaćeni provedenim empirijskim istraživanjem niti jedan ispitanik nema samo osnovnoškolsko obrazovanje, ali niti jedan ispitanik također nema ni doktorat. Najzastupljeniji stupanj obrazovanja među ispitanicima jest srednjoškolsko obrazovanje $(38,9 \%)$, zatim izučeni zanat $(27,4 \%)$, viša stručna sprema $(25,3 \%)$ te magisterij $(8,4 \%)$. Najveći broj ispitanika je u radnom odnosu, (70,1 \%). Nezaposlenih je svega 9,3 \% ispitanika, a umirovljenika ima $1 \%$. Studenata ima 16,5 \%, dok srednjoškolci čine 2,1\%. Odgovor ostalo dalo je $1 \%$ ispitanika. Najveći broj ispitanika koji su odgovorili na anketni upitnik o zadovoljstvu korisnika usluga javnog gradskog prijevoza u gradu Beču ima ukupna redovita primanja u zajedničkom kućanstvu preko 1.500 eura, čak $66 \%$. Od 2.000 eura do 4.000 eura prima 30,9\% ispitanih, od 4.000 eura do 7.000 eura prima 3,1 \% ispitanika, a preko 7.000 eura ne prima niti jedan ispitanik. 


\section{3 Zadovoljstvo korisnika uslugama javnog gradskog prijevoza}

U ovom dijelu rada prikazani su pokazatelji o zadovoljstvu korisnika uslugama koje omogućuje javni gradski prijevoz u gradu Beču. Navike korištenja javnog gradskog prijevoza u gradu Beču od strane stanovnika ovog austrijskog grada prikazane su u sljedećoj tablici. Na pitanje koliko često koriste javni gradski prijevoz grada Beča, 17,5 \% ispitanika odgovorilo je da javni gradski prijevoz koristi samo jednom tjedno. Dva puta tjedno javni gradski prijevoz koristi 18,6 \% ispitanika. Više od polovice ispitanih korisnika koristi javni gradski prijevoz u gradu Beču svaki dan. Samo manji broj ispitanika koristi javni gradski prijevoz jednom mjesečno ili nekoliko puta godišnje. Visoki postotak ispitanika koji javni gradski prijevoz koristi svakodnevno dobar je pokazatelj učinkovitosti javnog gradskog prijevoza u gradu Beču. Efikasna organizacija takvog složenog prometnog sustava svakako je temelj na kojem stanovnici grada Beča, u okviru provedenog empirijskog istraživanja ispitanici, svakodnevno donose odluke o intenzitetu korištenja javnog gradskog prijevoza.

Tablica 1. Učestalost korištenja javnog gradskog prijevoza u gradu Beču

\begin{tabular}{|l|c|}
\hline OPIS & $\%$ \\
\hline Jednom tjedno & 17,5 \\
\hline Dva puta tjedno & 18,6 \\
\hline Svaki dan & 51,5 \\
\hline Jednom mjesečno & 4,2 \\
\hline Nekoliko puta godišnje & 8,2 \\
\hline
\end{tabular}

Izvor: rezultati provedenog istraživanja

Na temelju tablice 2 jasno je vidljivo da su korisnici zadovoljni točnošću voznog reda. Od ukupnog broja ispitanika $53,6 \%$ zadovoljno je točnošću voznog reda, $44,3 \%$ izjasnilo se da je vrlo zadovoljno točnošću voznog reda, dok je svega $1 \%$ ispitanika poprilično nezadovoljno te također samo 1 $\%$ potpuno nezadovoljno. Na pitanje o zadovoljstvu učestalošću polazaka javnih gradskih prijevoznih sredstava u gradu Beču većina ispitanika odgovorila je pozitivno, odnosno njih $99 \%$, dok je nezadovoljstvo izrazilo samo $1 \%$ anketiranih ispitanika.

Tablica 2. Zadovoljstvo točnošću voznog reda javnog gradskog prijevoza

\begin{tabular}{|l|c|}
\hline OPIS & $\%$ \\
\hline Zadovoljan & 53,6 \\
\hline Vrlo zadovoljan & 44,3 \\
\hline Poprilično nezadovoljan & 1 \\
\hline Potpuno nezadovoljan & 1 \\
\hline
\end{tabular}

Izvor: rezultati provedenog istraživanja 
Često presjedanje tijekom gradske vožnje svakako ima utjecaj na zadovoljstvo korisnika usluga javnog gradskog prijevoza, budući da iziskuje dodatne napore korisnika i produžuje trajanje samog putovanja. Pomno planiranje linija javnog gradskog prijenosa, kao i adekvatno raspoređivanje polazaka tih linija od strane rukovoditelja sustava izuzetno su važni za zadovoljstvo korisnika, budući da smanjuju broj presjedanja i trajanje putovanja. Na tablici 3 prikazani su pokazatelji tolerancije presjedanja tijekom jedne vožnje javnim gradskim prijevozom u gradu Beču. Od ukupnog broja ispitanih korisnika usluga javnog gradskog prijevoza u gradu Beču 44,8 \% ispitanih tolerira tijekom jedne vožnje do 2 presjedanja između različitih ili istih prijevoznih sredstava, 40,6\% ispitanika odgovorilo je da tolerira do 3 presjedanja, dok njih 14,6\% tolerira i preko 3 presjedanja.

Tablica 3. Tolerancija presjedanja tijekom jedne vožnje

\begin{tabular}{|l|c|}
\hline OPIS & $\%$ \\
\hline Do 2 presjedanja & 44,8 \\
\hline Do 3 presjedanja & 40,6 \\
\hline Više od 3 presjedanja & 14,6 \\
\hline
\end{tabular}

Izvor: rezultati provedenog istraživanja

U sljedećoj tablici prikazani su odgovori ispitanika na pitanje kojim se prijevoznim sredstvom u javnom gradskom prijevozu grada Beča najčešće koriste. Autobusom i tramvajem ispitanici se podjednako voze; $23,7 \%$ ispitanika redovito koristi autobusom, $20,6 \%$ ispitanika često se vozi tramvajem. Najviši broj ispitanika u provedenom empirijskom istraživanju najčešće se koristi podzemnom željeznicom (U-Bahn) (53,6 \%). Gradskom željeznicom (S-Bahn) najčešće se koristi najmanje ispitanih korisnika usluga javnog gradskog prijevoza u gradu Beču $(2,1 \%)$. Razgranatost i dostupnost stanica podzemne željeznice kao dominantnog oblika javnog gradskog prijevoza u gradu Beču potvrđena je provedenim empirijskim istraživanjem, budući da se više od polovice ispitanika najčešće koristi upravo prije navedenim oblikom javnog gradskog prijevoza. Na pitanje o intenzitetu gužve unutar prijevoznih sredstava javnog gradskog prijevoza u gradu Beču većina ispitanika odgovorila je da je gužva unutar prijevoznog sredstva velika $(69,5 \%), 27,4 \%$ smatra da je gužva unutar prijevoznih sredstava jako velika, dok samo mali broj ispitanika $(3,1 \%)$ smatra da gužva nije velika.

Tablica 4. Najčešće korišteno prijevozno sredstvo

\begin{tabular}{|l|c|}
\hline OPIS & $\%$ \\
\hline Autobus & 23,7 \\
\hline Tramvaj & 20,6 \\
\hline Podzemna željeznica & 53,6 \\
\hline Gradska željeznica & 2,1 \\
\hline
\end{tabular}

Izvor: rezultati provedenog istraživanja 
Povezanost grada linijama i raspored stanica unutar gradskih četvrti bitan je kriterij učinkovitosti javnog gradskog prijevoza. Kvalitetno isplanirana povezanost različitih dijelova grada uvelike može povećati razinu zadovoljstva korisnika, ali i kvalitetu usluge, javnog gradskog prijevoza u bilo kojem urbanom središtu, pogotovo u većim gradovima, gdje su prometne gužve i nedostatak parkirnih mjesta svakidašnja pojava. Na pitanje o zadovoljstvu korisnika uslugama javnog gradskog prijevoza povezanošću dijelova grada Beča pozitivno je odgovorilo 95,8 \% ispitanika, dok je tek manji postotak ispitanika nezadovoljan njime.

Na zadovoljstvo korisnika usluga javnog gradskog prijevoza grada Beča utječe i stanje prijevoznih sredstava kojima se korisnici svakodnevno prevoze. Udobnost i čistoća prijevoznih sredstava značajan su faktor u zadovoljenju potreba korisnika kada se govori o prijevozu. $U$ anketnom upitniku ispitanici su ocijenili udobnost prijevoznih sredstava. Niti jedan ispitanik nije ocijenio udobnost vozila nezadovoljavajućom, 12,5 \% ispitanika ocijenilo je udobnost zadovoljavajućom, dok je više od polovice ispitanika udobnost vozila ocijenila dobrom $(64,6 \%)$. Tek manji udio ispitanika smatra da je udobnost jako dobra (17,7 \%) i odlična (5,2 \%).

Kod pitanja o čistoći prijevoznih sredstava provedenim istraživanjem ustanovljeno je da je 18,6 $\%$ ispitanika potpuno zadovoljno unutarnjom čistoćom prijevoznih sredstava, 74,2 \% ispitanika je dalo odgovor da su zadovoljni, njih 4,1 \% potpuno je nezadovoljno, dok je 3,1\% ispitanika nezadovoljno.

Osjećaj sigurnosti vožnje isto je vrlo važan čimbenik u stvaranju zadovoljnog korisnika. Ispitanici su u provedenom empirijskom istraživanju dali ocjene sigurnosti vožnje javnog gradskog prijevoza u Beču. Za 1 \% od ukupnog broja ispitanih sigurnost vožnje je nedovoljna, 15,5 \% smatra da je zadovoljavajuća. 55,7 \% ispitanika dalo je odgovor da je sigurnost dobra, a njih 20,6 \% da je jako dobra. Za 7,2 \% ispitanika sigurnost vožnje u javnom gradskom prijevozu grada Beča odlična je.

Tablica 5. Načini plaćanja vozne karte

\begin{tabular}{|l|c|}
\hline OPIS & $\%$ \\
\hline Godišnja karta & 29,9 \\
\hline Mjesečna karta & 43,3 \\
\hline Jednokratna karta & 18,6 \\
\hline Drugo & 8,2 \\
\hline
\end{tabular}

Izvor: rezultati provedenog istraživanja

U provedenom istraživanju većina ispitanika ocijenila je vlastito zadovoljstvo većine varijabli u javnom gradskom prijevozu grada Beča visokom razinom. Jedna od rijetkih varijabli kojom su korisnici javnog gradskog prijevoza iskazali nezadovoljstvo jest cijena vozne karte. Od ukupnog broja ispitanika 55,2 \% ispitanika ocijenilo je vlastito zadovoljstvo cijenom prijevozne karte negativnim. S druge strane, zadovoljstvo dostupnošću mjesta za kupnju prijevoznih karata ocijenjeno je zadovoljavajuć (57,3 \%), dok je njime nezadovoljno 42,7\% ispitanika. U tablici 5 prikazani su modaliteti kupnje prijevoznih karata te je ustanovljeno da većina ispitanika (43,3\%) kupuje mjesečne prijevozne karte, 29,9\% ispitanika kupuje godišnju kartu, 18,6\% koristi jednokratne karte 
dok tek 8,2 \% ispitanika koristi druge načine plaćanja, odnosno kupnje prijevoznih karti u javnom gradskom prijevozu grada Beča.

Tablica 6. Općenito zadovoljstvo korisnika usluga javnog gradskog prijevoza

\begin{tabular}{|l|c|}
\hline OPIS & $\%$ \\
\hline Potpuno nezadovoljan & 1 \\
\hline Poprilično nezadovoljan & 2,1 \\
\hline Poprilično zadovoljan & 34 \\
\hline Vrlo zadovoljan & 60,8 \\
\hline Ne mogu procijeniti & 2,1 \\
\hline
\end{tabular}

Izvor: rezultati provedenog istraživanja

Anketni upitnik omogućio je i odgovor na općenito zadovoljstvo korisnika usluga javnog gradskog prijevoza uzimajući u obzir ukupnost varijabli, odnosno ukupnu razinu zadovoljstva ispitanika cjelokupnim doživljajem i korištenjem usluge javnog gradskog prijevoza u gradu Beču. Od ukupnog broja ispitanika samo je $1 \%$ potpuno nezadovoljnih, 2,1 \% je poprilično nezadovoljno, $34 \%$ je poprilično zadovoljno, dok je većina ispitanika vrlo zadovoljna uslugama javnog gradskog prijevoza. Tek 2,1 \% ispitanika ne može procijeniti je li zadovoljno ili nije uslugama javnog gradskog prijevoza u gradu Beču.

\section{4 Prisutnost marketinških aktivnosti u javnom gradskom prijevozu}

Prema Grbcu (2007) marketing predstavlja poslovnu funkciju kojom tržišni subjekti, poduzeća i organizacije prepoznaju želje i potrebe potrošača, utvrđuju ciljne segmente kojima mogu ponuditi svoje usluge ili proizvode i konstruiraju svoju ponudu, odnosno kombinaciju elemenata marketing miksa koja će u budućnosti polučiti najbolje rezultate.

Poduzeća i organizacije čija je djelatnost javni gradski prijevoz sve više prepoznaju značajnost marketinga u obavljanju svojih djelatnosti, i to pogotovo u slučaju kada su već poboljšali operativnu prometnu učinkovitost vlastitih prometnih sustava. Strateška važnost marketinških aktivnosti sve više dobiva pozornost različitih rukovoditelja takvih sustava te se sektor javnog gradskog prijevoza sve više tržišno orijentira (Cronin, Hightower, 2004). Najvažnije funkcije koje marketing, odnosno marketinške aktivnosti unutar poduzeća ili organizacije javnog gradskog prijevoza moraju ostvariti jest da takve aktivnosti moraju voditi pribavljanju novih novčanih priljeva, odnosno prihoda. Osim navedenog, poduzeća ili organizacije, osim što mogu oglašavati druge komercijalne poslovne objekte na površinama izvan i unutar svojih javnih gradskih prijevoznih sredstava, isto mogu koristiti i za učinkovito oglašavanje vlastitih usluga koje razvijaju ili unaprjeđuju, te i na taj način pridonijeti priljevu novih prihoda u vlastito poduzeće ili organizaciju (Cronin, Hightower, 2004). $U$ današnje suvremeno doba iskorištavanje mogućnosti oglašavanja u javnom gradskom prijevozu dio je kvalitetnog odnosa s javnošću navedenih poduzeća i organizacija, koji spomenutim putem mogu adekvatno komunicirati sa širokim spektrom potrošača, odnosno korisnika usluga javnog 
gradskog prijevoza. $U$ današnjem suvremenom svijetu velikih napredaka tehnologije, kada se radi o marketinškim aktivnostima i aktivnostima oglašavanja u gradu Beču, više se ne može govoriti o plakatima koji su se donedavno koristili za reklamiranje. Sada se intenzivno koriste informacijski zasloni postavljeni u autobuse, tramvaje i stanice podzemne željeznice na kojima se svakodnevno mijenja stotine reklamnih oglasa. Poduzeće Wiener Linien je 2012. godine prihvatilo ponudu vodećeg austrijskog poduzeća u području vanjskog oglašavanja Gewista. Oko $30 \%$ trajanja reklamnog prostora na informacijskim zaslonima puštaju se reklamni oglasi, dok se u preostalom vremenu puštaju informacije o presjedanjima, stanicama te ostalim informacijama vezanima uz vožnju (diepresse.com, 2016).

Postoji niz motiva kao što su smanjenje troškova, smanjenje trajanja putovanja ili ekološka osviještenost, zbog kojih sve više građana koristi javni gradski prijevoz za put u školu, posao ili u slobodno vrijeme, $s$ raznovrsnom ponudom reklamnih oglasa na prijevoznim sredstvima javnog prometa u gradu Beču. Spomenuto poduzeće Gewista dobilo je titulu najuspješnijeg reklamnog poduzeća vanjskog oglašavanja u Austriji. Faktor uspjeha ove reklamne agencije je ideja da ljudi vole neobične, atraktivne autobuse i tramvaje u potpunosti pokrivene reklamnim oglasima. Ono što je bitno za mogućnost oglašavanja u prometu je da $70 \%$ korisnika vozila gradskog prometa putuje 5 do 6 puta tjedno istom rutom. Idealni reklamni oglasi pojavljuju se kao kombinacija plakata, svjetlećih reklama, rotacijskih stupova i slično. Reklamni oglasi na stanicama, kolodvorima i stanicama podzemne željeznice od 2014. godine nude kombinaciju različitih digitalnih medija (uključujući i aplikacije za mobilne uređaje) koji su se pokazali kao veoma uspješni (www.gewista. at, 2016).

Provedenim empirijskim istraživanjem pokušalo se od korisnika javnog gradskog prijevoza u gradu Beču saznati kakva je njihova percepcija prisutnosti marketinških aktivnosti unutar i izvan prijevoznih sredstava u sustavu javnog gradskog prijevoza grada Beča, te u konačnici - utječe li prisutnost marketinških aktivnosti na zadovoljstvo korisnika usluga javnog gradskog prijevoza. $U$ tablici 7 prikazani su rezultati, odnosno odgovori ispitanika na pitanje kakva je njihova percepcija kvantitete marketinških aktivnosti, odnosno reklamnih oglasa u javnom gradskom prijevozu grada Beča.

Tablica 7. Percepcija kvantitete marketinških aktivnosti

\begin{tabular}{|l|c|}
\hline OPIS & $\%$ \\
\hline Jako velika & 33 \\
\hline Velika & 62,9 \\
\hline Mala & 3,1 \\
\hline Neprimjetna & 1 \\
\hline
\end{tabular}

Izvor: rezultati provedenog istraživanja

Najveći broj ispitanika odgovorio je da je prisutnost marketinških aktivnosti, odnosno reklamnih oglasa u javnom gradskom prijevozu grada Beča, velika (62,9\%), $33 \%$ ispitanika odgovorilo je da je prisutnost reklamnih oglasa jako velika, 3,1 \% ispitanika odgovorilo je da je mala, a samo 1 
$\%$ da je prisutnost marketinških aktivnosti neprimjetna. Dobiveni rezultati navode na činjenicu, uzimajući u obzir i dobivene rezultate o općenitom zadovoljstvu i drugim varijablama, da prisutnost marketinških aktivnosti nema velik utjecaj na zadovoljstvo korisnika usluga javnog gradskog prijevoza, budući da većina ispitanika ipak prisutnost reklamnih oglasa ne smatra prevelikom, odnosno da postoji određen stupanj tolerancije. Vidljivost reklamnih oglasa unutar, izvan i na prijevoznim sredstvima izuzetno je bitna značajka u pogledu dosega promotivnih poruka poslovnih subjekata koji se oglašavaju, ali i poduzeća Wiener Linien. Na pitanje obraćaju li pažnju na reklamne oglase unutar vozila potvrdno je odgovorilo $86,2 \%$ ispitanika. Vidljivost, učestalost i doseg promotivnih poruka poduzeća Wiener Linien koje obavlja javni gradski prijevoz u gradu Beču na adekvatnoj je razini, te je $64,6 \%$ ispitanika odgovorilo da često primjećuje reklamne oglase spomenutog poduzeća, 30,2 \% ponekad, dok $5,2 \%$ gotovo nikad.

\section{ZAKLJUČAK}

Javni gradski prijevoz važan je čimbenik u funkcioniranju grada kao cjeline. Zadovoljiti potrebe korisnika unutar okvira javnog gradskog prijevoza znači omogućiti brz, udoban, jeftin i učinkovit prijevoz. Učinkovit prijevoz, shodno tome, ima ključnu ulogu u unaprjeđenju kvalitete življenja stanovnika gradova. Smanjuju se zagušenja u prometu, emisije štetnih plinova, razine intenziteta buke te se ispravno koristi vrijeme svakog pojedinca omogućujući mu točan i brz dolazak na destinaciju njegovog putovanja.

$\mathrm{Na}$ osnovi provedenog empirijskog istraživanja i prikazanih pretpostavki javnog gradskog prijevoza u gradu Beču koje su navedene u ovom radu može se zaključiti da je grad Beč dobrom organizacijom prometa te pravovremenim unaprjeđenjima i savjesnim izvršavanjem svih zadataka postigao zadovoljstvo korisnika. Učinkovitim radom prometnog poduzeća Wiener Linien i dobrom komunikacijom između korisnika i davatelja usluga postignut je odlično organiziran prometni sustav. Na temelju rezultata provedene ankete o zadovoljstvu korisnika usluga javnog gradskog prijevoza u Beču vidljivo je da većina korisnika (51,5\%) ovoga grada svakodnevno putuje javnim gradskim prijevozom te da su uslugama istog vrlo zadovoljni (60,8 \%). Većina ispitanika zadovoljna je točnošću voznog reda, što potvrđuju kretanja vozila javnog gradskog prijevoza u točno dogovoreno vrijeme. Kada se radi o učestalosti polazaka javnih gradskih prijevoznih sredstava gotovo svi ispitanici izjasnili su se da su veoma zadovoljni. Korisnici su u najvećem broju udobnost vozila ocijenili dobrom ocjenom, a unutarnju čistoću vozila smatraju zadovoljavajućom. Sigurnost vožnje po mišljenju više od polovice korisnika je dobra, no kada se radi o cijeni, više od pola ispitanika izražava nezadovoljstvo cijenom. $U$ stavu o dostupnosti mjesta za prodaju voznih karata mišljenja ispitanika podijeljena su; jedan dio ispitanika (42,7\%) smatra dostupnost nezadovoljavajućom, dok je ona za 57,3 \% ispitanika zadovoljavajuća. Na toleranciju u vezi s presjedanjima ne može se puno utjecati; cilj putovanja ponekad zahtijeva velik broj presjedanja. Mišljenja o tome koliko presjedanja tolerira putnik različita su od pojedinca do pojedinca. Većina ispitanih u ovoj anketi tolerira do dva presjedanja. Za najčešće korišteno prijevozno javno gradsko sredstvo većina ispitanika izabrala je podzemnu željeznicu, a što se tiče načina plaćanja karti, putnici najčešće biraju mjesečne karte. Po mišljenju korisnika prisutnost marketinških aktivnosti u prometu je velika te većina njih svakodnevno primijeti razne reklamne oglase. 
Shodno dobivenim rezultatima i provedenim empirijskim istraživanjem može se odgovoriti na istraživačka pitanja postavljena u radu te je potvrđeno zadovoljstvo korisnika usluga javnog gradskog prijevoza u gradu Beču. Prisutnost marketinških aktivnosti u javnom gradskom prijevozu visokog je intenziteta, no korisnici usluga javnog gradskog prijevoza ne percipiraju spomenutu prisutnost negativnim faktorom kada se govori o ukupnom zadovoljstvu. Uz kvalitetnu uslugu vežu se zadovoljni korisnici. Zadovoljan korisnik temelj je dobre prometne organizacije. Zadovoljan korisnik govori o svome zadovoljstvu nekolicini, dok će nezadovoljan korisnik o svome nezadovoljstvu govoriti puno većem broju ljudi.

Metodoloških ograničenja u provođenju predmetnog istraživanja bilo je nekoliko. Zbog utjecaja metodoloških ograničenja na dobivene rezultate $u$ provedenom empirijskom istraživanju, mogućnost donošenja zaključaka smanjena je. $U$ istraživanju je korišten anketni upitnik te se korisnike usluga javnog gradskog prijevoza grada Beča ispitivalo usmeno. Dio ispitanika ispunio je anketni upitnik na društvenim mrežama ili e-mailom. Anketa je provođena većim dijelom usmenim putem pa je, budući da je kvalitetno ispunjavanje zahtijevalo duže vrijeme, obujam anketnog upitnika bio otežavajući čimbenik, a velik dio korisnika kojima se pristupilo za ispunjavanje anketnog upitnika odbio sudjelovanje u istraživanju. Nedostatkom se može smatrati i činjenica da određeni dio ispitanika nije odgovarao ono što zaista misli, već ono za što smatra da je prihvatljivo. Još jednim metodološkim ograničenjem može se smatrati i mali broj ispitanika (97). Preporuke za daljnja istraživanja zadovoljstva korisnika usluga javnog gradskog prijevoza proizlaze iz prije navedenih ograničenja. Anketnim upitnikom može se doći do korisnih informacija ako se upitnik sastavi uz primjeren problem istraživanja, reprezentativan broj ispitanika i uz adekvatnu pribavu podataka. Važno je napomenuti da se ispitanici osjećaju sigurnije kada se ispitivanje obavlja pismenim putem upravo zbog veće anonimnosti samih ispitanika. Shodno tome mogu dati iskrenije i potpunije odgovore, što vodi boljim konačnim rezultatima empirijskog istraživanja.

\section{LITERATURA}

CarSharing Association (2011) CarSharing Association Code of Ethics and Standards of Practice, str. 2, web stranica, dostupno na: http://carsharing.org/wp-content/uploads/2011/02/CarSharingAssociation_Codeof Ethics.pdf, 3. 3. 2017.

Cronin, J. J., Hightower, R. (2004) An Evaluation of the Role of Marketing in Public Transit Organizations, Journal of Public Transportation, 7(2), p. 17-21

European Commission (2014) Europeans' satisfaction with urban transport, str. 4, web stranica, dostupno na: http:// ec.europa.eu/public_opinion/flash/fl_382b_en.pdf(28. 2. 2017.)

Grbac, B. (2007) Načela marketinga, Rijeka: Ekonomski fakultet sveučilišta u Rijeci

https://homepage.univie.acat (2017), web stranica, pristupljeno (1. 3. 2017.)

https://www.diepresse.com (2016), web stranica, pristupljeno (26. 12. 2016.)

https://www.gewista.at (2016), web stranica, pristupljeno (29. 12. 2016.)

https://www.wien.gv..at (2017), web stranica, pristupljeno (1.3. 2017.)

https://www.wienerlinien.at (2016), web stranica, pristupljeno (28. 12. 2016.)

Mouwen, A. (2015) Drivers of Customer Satisfaction with Public Transport Services, Transportation Research: Part A: Policy And Practice, 78, p. 1-20 
Pupavac, D. (2009) Načela ekonomike prometa, Rijeka: Veleučilište u Rijeci

Rajsman, M. (2012) Tehnologija cestovnog prometa, Zagreb: Fakultet prometnih znanosti, p. 199-210

Shiau, W., Luo, M. M. (2012) Factors affecting online group buying intention and satisfaction: A social exchange theory perspective, Computers In Human Behavior, 28(6), p. 2431-2444

Wiener Linien Gmbh \& Co KG (2015) Facts and Figures, str. 2, web stranica, dostupno na: http://www.wienerlinien.at/ media/files/2016/facts_and_figures_2015_178361.pdf (1.3. 2017.)

Zamazalová, M. (2009) Marketing obchodnífirmy, Praha: Grada. U: Pawlasová, P., (2015) The Factors Influencing Satisfaction with Public City Transport: A Structural Equation Modelling Approach, Journal of Competitiveness, 7(4), p. 18 - 32 


\title{
CUSTOMER SATISFACTION WITH PUBLIC TRANSPORT SERVICES IN THE CITY OF VIENNA ${ }^{4}$
}

\begin{abstract}
Public transport includes different types of services that enable the mobility of citizens and residents of cities, it includes buses, trains, subways, ferries, taxis and their variations. Public transport can have a very important and unique role in the system of public transport in a way that allows affordable mobility of citizens who are not drivers and offers an efficient way to travel in urban areas and often serves as a catalyst for more thoughtful and better management of public lands within the public transport infrastructure. This paper briefly outlines the public transport system of the city of Vienna. In today's modern cities, traffic is one of the biggest problems. Big cities are too burdened by traffic congestion, lack of parking space, polluted air, noise and conflict of motor vehicles and pedestrians. All of these problems in which traffic demand exceeds the traffic offer does not stand for public transport this European city provides to its citizens. City management and leading Transport Company Wiener Linien is making great efforts in the reduction of traffic congestion and traffic pollution. To encourage users to use public transport and reduce the use of cars, the city of Vienna offers the services of renting city bikes and using a large number of cycle routes, car sharing, etc. The aim of this paper is to investigate and determine customer satisfaction with public transport in the city of Vienna using questionnaire.
\end{abstract}

Key words: public transport, services, customer satisfaction

MSc, Lecturer, Polytechnic of Rijeka, Vukovarska 58, 51000 Rijeka, Croatia. E-mail: mgolob@veleri.hr Student, Polytechnic of Rijeka, Vukovarska 58, 51000 Rijeka, Croatia.

Univ. spec. oec., Assistant, Polytechnic of Rijeka, Vukovarska 58, 51000 Rijeka, Croatia. E-mail: martin.golob@veleri.hr Received: 15 January 2017; Accepted: 15 March 2017 